\title{
ABSTRACTS OF MEMOIRS
}

\section{RECORDING WORK AT THE PLYMOUTH LABORATORY}

CoOper, L. H. N., 1977. An hypothesis of a continuous ice dam between Greenland and Scotland during the Quaternary. In Polar Oceans: Proceedings of the Polar Oceans Conference, McGill University, Montreal, May 1974 (ed. M. J. Dunbar), pp. 633-641. Calgary, Alberta: Arctic Institute of North America.

The hypothesis is erected that during the Quaternary an ice dam built up from icebergs grounding on the foundation provided by the submarine ridge which joins Greenland through Iceland and the Faroes to Scotland. To the northward in time much water became ponded. A seismic event weakened the foundation initiating a small flow of Arctic water into the Atlantic. This small flow developed cataclysmically into a stupendous torrent able to excavate the Faroe Bank Channel in a few hours or days.

A number of tests of the hypothesis are suggested.

Findlay, I. \& McVean, A., 1977. The nervous control of limb autotomy in the hermit crab Pagurus bernhardus (L.) and the role of the cuticular stress detector, $\mathrm{CSD}_{1}$. Fournal of Experimental Biology, 70, 93-104.

Limb autotomy results from the fracture of a preformed breakage plane within the second limb segment. Fracture is produced by the contraction of the large anterior levator (AL) muscle at the same time as its synergist, the posterior levator (PL) muscle. The $\mathrm{AL}$ force is thus directed on to a small portion of the breakage plane; withdrawal of this plug initiates cuticular fracture. Autotomy is a response to damage inflicted on the limb. In the absence of sensory information from the second limb segment there is less activity in the units serving the PL. It is shown that stimulation of the sense organ, cuticular stress detector one, provides feedback to PL motor neurones. The feedback is an integral part of the nervous control of limb autotomy.

Flood, P. R., 1978. Filter characteristics of appendicularian food catching nets. Experientia, 34, 173-175.

Scanning electron micrographs reveal extensive filter surfaces in the external food catching net of planktonic appendicularia. This filter consists of crossing arrays of filaments about $0.04 \mu \mathrm{m}$ thick and pores about $0.24 \times 0.07 \mu \mathrm{m}$ wide. The open area fraction is above $50 \%$. The filter probably enables the appendicularia to feed efficiently on particles much smaller than bacteria.

FretTer, V. \& MANLy, R., 1977. The settlement and early benthic life of Littorina neritoides (L.) at Wembury, S. Devon. Fournal of Molluscan Studies, 43, 255-262.

Veligers of Littorina neritoides settle within the lowest $\frac{1}{2} \mathrm{~m}$ of a quartzite rock which rises sharply shoreward from above M.H.W.N. to $2.5 \mathrm{~m}$. The newly metamorphosed snails, conspicuous on account of their glossly, semitransparent, chestnut-brown shells, are most frequent within crystal pits; the diameter of the smallest collected was $0.4 \mathrm{~mm}$ and height $0.37 \mathrm{~mm}$. They settle when a tide exceeding $4.95 \mathrm{~m}$ covers the area and when spray of neap tides surges against it. When settlement is good in April and September there are densities of 22-52 $\mathrm{m}^{-2}$; occasionally very large aggregations of larvae settle.

Shell measurements indicate that the snail remains where it settles for about $24 \mathrm{~h}$ feeding on algae on the rock and attaining a shell diameter approximately $1 \mathrm{~mm}$. Radial enlargement of the shell precedes elongation at aperture: this presumably begins in the veliger and ends when calcification is advanced and the shell becomes opaque about $6 \mathrm{~h}$ after settlement. When the snail leaves the settlement site it exhibits the negative geotaxis characteristic of adults. 
HARRIS, R. P., 1977. Some aspects of the biology of the harpacticoid copepod, Scottolana canadensis (Willey), maintained in laboratory culture. Chesapeake Science, 18, 245-252.

The epibenthic harpacticoid Scottolana canadensis can be maintained over multiple generations on a diet of the flagellate Isochrysis galbana and the diatom Thalassiosira pseudonana at 20 and $25^{\circ} \mathrm{C}$. Adult females lived on average for $77^{.8}$ days during which the mean number of eggs produced was $406 \cdot 8$. The maximum number of eggs produced by a single female was 817 . Both brood size and rate of egg production increase with increasing quantity of food available until a level is reached above which there is no further increase in fecundity.

Holme, N. A. \& Probert, P. K., 1978. Disposal of solid waste in the marine environment with particular reference to the china clay industry. In Environmental Management of Mineral Wastes (ed. G. T. Goodman and M. J. Chadwick), pp. 239-253. Alphen aan den Rijn, The Netherlands: Sijthoff and Noordhoff.

China clay deposits in the South West of England, derived from the kaolinization of feldspar contained in the granite intrusions of Cornwall, have been extensively mined in open pits since the eighteenth century. Jets of water break up the friable granite and the china clay is separated from residues in settling tanks. The finer fractions of the residues, which are rich in mica, have in the past been discharged to the sea, particularly Mevagissey Bay, via various rivers.

Although this practice is now being discontinued, an estimated 17000000 tons of fine micaceous waste material has been discharged into Mevagissey Bay by the White River since mining began. This gives a dense 'white-water' plume at the sea surface, often with an abrupt boundary.

The material is non-toxic and although experiments have shown that high concentrations of suspended solids may cause gill damage in freshwater fish, no gill damage has been observed in fish taken from Mevagissey Bay. Deposition of fine material on a former rocky surface suitable for crab or lobster fishing produces a smooth soft surface which may eventually become suitable for trawl-fishing.

Experiments to determine whether pipeline discharge of the waste to the sea-bed would result in effective dispersal of the wastes were inconclusive, and since it was uncertain whether beach pollution could be avoided completely the pipeline scheme was abandoned.

Meves, H., 1978. Inactivation of the sodium permeability in squid giant nerve fibres. Progress in Biophysics and Molecular Biology, 33, 207-230.

Inactivation of the sodium permeability is the process underlying the falling phase of the action potential and the subsequent refractory period. During the last years much experimental work concerning the inactivation process has been done, in particular on intracellularly perfused squid giant axons. This review article summarizes the experimental work. The new experimental material is conveniently divided into the following five chapters: (a) partial or complete removal of sodium inactivation by intracellularly applied substances which affect proteins, $(b)$ the time constant of sodium inactivation $\left(\tau_{h}\right)$ as measured with different pulse programmes and under different experimental conditions, $(c)$ incomplete and slow inactivation as opposed to the classical fast inactivation process described by the inactivation variable $h$ of Hodgkin \& Huxley (1952), (d) experiments concerning the question whether activation and inactivation are independent or coupled processes, $(e)$ measurements of the intramembrane charge movement (which is probably in some way related to the function of the sodium gates) and of its inactivation.

OtT, F. S., HARRIs, R. P. \& O'HARA, S. C. M., 1978. Acute and sublethal toxicity of napthalene and three methylated derivatives to the estuarine copepod, Eurytemora affinis. Marine Environmental Research, 1, 49-58.

The bi-cyclic aromatic hydrocarbon naphthalene $(N)$ and its alkylated derivatives 2-methylnaphthalene $(\mathrm{MN}), 2,6$-dimethylnaphthalene $(\mathrm{DMN})$ and 2,3,5-trimethylnaphthalene (TMN) were used to investigate possible relationships between increased methylation and toxicity during acute high level and chronic low level exposure experiments using the calanoid copepod Eurytemora affinis Poppe. The $24 \mathrm{~h} \mathrm{LC}_{50}$ levels determined indicated an approximate twofold increase in toxicity per methyl group addition: $\mathrm{N}, 3798 \mu \mathrm{g} / 1 ; \mathrm{MN}, 1499 \mu \mathrm{g} / 1 ; \mathrm{DMN}, 852 \mu \mathrm{g} / 1$ and TMN, 
$316 \mu \mathrm{g} / \mathrm{l}$. Low level chronic exposure of $E$. affinis to the various naphthalenes in sea-water concentrations of about $10 \mu \mathrm{g} / 1$ for the duration of their adult life (maximum 29 days) resulted in significant reductions in length of life, total numbers of nauplii produced and mean brood size. Exposure to all the naphthalenes at this level $(\bumpeq 10 \mu \mathrm{g} / \mathrm{l})$ resulted in reduced rates of egg production which were, on average, about $50 \%$ of those of control animals. Results are discussed in relation to previous work on the fate and effect of petroleum hydrocarbons in marine copepods.

Paul, D. H., Roberts, B. L. \& Ryan, K. P., 1977. Comparisons between the lateral-line lobes of the dogfish and the cerebellum: an ultrastructural study. Fournal für Hirnforschung, 18, 335343 .

The lateral-line lobes of the hindbrain of the dogfish (Scyliorhinus canicula) were studied by electron microscopy. The lobes comprise a complex neuropil covered by a molecular layer that consists of unmyelinated axons, dendrites and small stellate-like interneurons. The secondary sensory neurons are elongate multipolar cells that give rise to large dendrites that spread into the molecular layer where they branch and become regularly spiny, and smaller dendrites that pass ventrally through the neuropil. Much of the neuropil comprises unmyelinated lateral-line afferent fibres that frequently form large, vesicle-filled swellings (2-5 $\mu \mathrm{m}$ diameter) that make numerous synaptic connexions with large neuron dendritic surfaces. These swellings are themselves contacted at times by axons (axo-axonal synapses) of unknown origin. Most of the large cell body is invested in glial coats, broken only occasionally by the presence of synaptic terminals. Some small terminals connect directly onto the cell body while others arise from unmyelinated axons that run along the soma surface and dendrites making multiple en passant contacts.

Stellate cells have spherical cell bodies that contain lightly staining cytoplasm and a surface indented by closely spaced nerve terminals derived from the parallel fibres, small unmyelinated axons ( $0.24 \mu \mathrm{m}$ diameter) that are arranged approximately parallel to each other, and which fill most of the molecular layer. These axons swell periodically and make en passant connexions with the spines of the large cell dendrites and with the stellate neurons.

This study has emphasized the close similarity in structure between the lobe molecular layer and the cerebellar molecular layer, both in neuronal content and organization, but the significance of this arrangement in terms of lateral-line function remains unclear.

Pingree, R. D. \& MAdDock, L., 1978. The $M_{4}$ tide in the English Channel derived from a nonlinear numerical model of the $M_{2}$ tide. Deep-Sea Research, 25, 53-63.

The results of a numerical model of the $\mathrm{M}_{4}$ tide in the English Channel are described and compared with known data from Channel ports. The relative importance of the non-linear terms in generating the $M_{4}$ tide and the effect of the frictional term in dissipating the $M_{4}$ is examined.

Southward, E. C., 1975. Pogonophora. In Reproduction of Marine Invertebrates, vol. 2 (ed. A. C. Giese and J. S. Pearse), pp. 129-156. Academic Press.

Asexual reproduction, by fragmentation, is rare in pogonophorans. Sexual reproduction is reviewed, with consideration of the anatomy of the male and female reproductive systems, spermatogenesis, oogenesis, spawning, embryonic development and settlement of larvae. The systematic position of the Pogonophora is briefly discussed. The cleavage of the egg is distorted by yolk and the shape of the egg, but the development of the coelom and the arrangement of setae on the posterior segments suggest some relationship to the Annelida.

Southward, E. C., 1977. A new species of Hyalinoecia (Polychaeta: Eunicidae) from deep water in the Bay of Biscay. In Essays on Polychaetous Annelids, in Memory of Dr Olga Hartman (ed. D. J. Reish and K. Fauchald), pp. 173-187. Los Angeles, University of Southern California, Allan Hancock Foundation. (Special publication.)

Hyalinoecia robusta is distinguished from $H$. tubicola, the common European quill-worm, by its larger and more robust tube, lack of eyes, globular frontal antennae and the occurrence of the

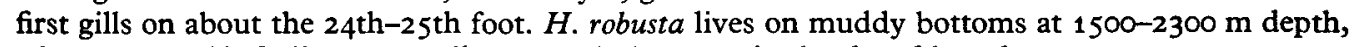
whereas $H$. tubicola lives generally on sandy bottoms in depths of less than $300 \mathrm{~m}$. 